\title{
Antidepressants, antimicrobials or both? Gut microbiota dysbiosis in depression and possible implications of the antimicrobial effects of antidepressant drugs for antidepressant effectiveness
}

\author{
Danielle Macedo ${ }^{\mathrm{a}, 1, *}$, Adriano José Maia Chaves Filho ${ }^{\mathrm{a}, 1}$, Caren Nádia Soares de Sousa ${ }^{\mathrm{a}}$, \\ João Quevedo $^{\mathrm{b}, \mathrm{c}, \mathrm{d}, \mathrm{e}}$, Tatiana Barichello ${ }^{\mathrm{b}, \mathrm{d}, \mathrm{e}, \mathrm{f}}$, Hélio Vitoriano Nobre Júnior ${ }^{\mathrm{g}}$, \\ David Freitas de Lucena ${ }^{a}$
}

\footnotetext{
${ }^{a}$ Neuropharmacology Laboratory, Drug Research and Development Center, Department of Physiology and Pharmacology, Faculty of Medicine, Federal University of Ceará, Fortaleza, CE, Brazil

b Translational Psychiatry Program, Department of Psychiatry and Behavioral Sciences, McGovern Medical School, The University of Texas Health Science Center at Houston (UTHealth), Houston, TX, USA

c Center of Excellence on Mood Disorders, Department of Psychiatry and Behavioral Sciences, McGovern Medical School, The University of Texas Health Science Center at Houston (UTHealth), Houston, TX, USA

d Neuroscience Graduate Program, The University of Texas Graduate School of Biomedical Sciences at Houston, Houston, TX, USA

e Laboratory of Neurosciences, Graduate Program in Health Sciences, Health Sciences Unit, University of Southern Santa Catarina (UNESC), Criciuma, SC, Brazil

${ }^{\mathrm{f}}$ Laboratory of Experimental Microbiology, Graduate Program in Health Sciences, Health Sciences Unit, University of Southern Santa Catarina (UNESC), Criciúma, SC, Brazil

g Laboratory of Bioprospection and Experiments in Yeast (LABEL), Drug Research and Development Center, Federal University of Ceará, Fortaleza, CE, Brazil
}

\section{A R T I C L E I N F O}

\section{Keywords:}

Antidepressants

Antimicrobials

Dysbiosis

Depression

Gut microbiota

\begin{abstract}
A B S T R A C T
Objectives: The first drug repurposed for the treatment of depression was the tuberculostatic iproniazid. At present, drugs belonging to new classes of antidepressants still have antimicrobial effects. Dysbiosis of gut microbiota was implicated in the development or exacerbation of mental disorders, such as major depressive disorder (MDD). Based on the current interest in the gut-brain axis, the focus of this narrative review is to compile the available studies regarding the influences of gut microbiota in behavior and depression and to show the antimicrobial effect of antidepressant drugs. A discussion regarding the possible contribution of the antimicrobial effect of antidepressant drugs to its effectiveness/resistance is included.

Methods: The search included relevant articles from PubMed, SciELO, LILACS, PsycINFO, and ISI Web of Knowledge.

Results: MDD is associated with changes in gut permeability and microbiota composition. In this respect, antidepressant drugs present antimicrobial effects that could also be related to the effectiveness of these drugs for MDD treatment. Conversely, some antimicrobials present antidepressant effects.

Conclusion: Both antidepressants and antimicrobials present neuroprotective/antidepressant and antimicrobial effects. Further studies are needed to evaluate the participation of antimicrobial mechanisms of antidepressants in MDD treatment as well as to determine the contribution of this effect to antidepressant resistance.
\end{abstract}

\footnotetext{
Abbreviations: ACTH, adrenocorticotropic hormone; BDNF, Brain-derived neurotrophic factor; CCL2, , Chemokine (C-C Motif) Ligand 2); CMS, chronic mild stress; CNS, central



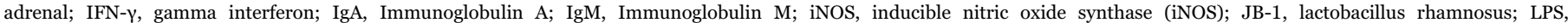



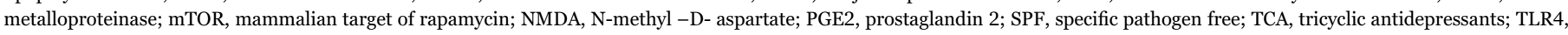
toll-like receptor 4; TNF- $\alpha$, tumor necrosis factor alpha

* Correspondence to: Neuropharmacology Laboratory, Drug Research and Development Center, Department of Physiology and Pharmacology, Federal University of Ceará, Rua Cel, Nunes de Melo 1000, 60430-270 Fortaleza, CE, Brazil.

E-mail addresses: daniellesilmacedo@gmail.com, danielle.macedo@ufc.br (D. Macedo).

${ }^{1}$ These authors contributed equally and should be considered co-first authors.
} 


\section{Introduction}

Major depressive disorder (MDD) is a common and recurrent psychiatric illness associated with significant morbidity and social burden (Nemeroff, 2007). In 2010, the Global Burden Study (GBD) considered MDD the 19th most prevalent disease in the world and the second leading cause of disability (Ferrari et al., 2013; Vos et al., 2012). The major consequence of MDD is suicide, a public-health problem (Jenkins, 2002). Also, depression has been associated with increased risk of severe chronic diseases, such as atherosclerotic heart disease and stroke (Clarke and Currie, 2009). Therefore, these findings emphasize the relevance of depression as a public-health problem and the implementation of effective interventions to reduce its burden.

The first drug used for depression treatment was iproniazid in the 1950s. The choice of this drug was based on its euphoric effects in tuberculosis patients (López-Muñoz and Alamo, 2009). At that moment, the discovery of iproniazid antidepressant effects was especially important because it could relegate Ugo Cerletti's electroconvulsive therapy, the only antidepressant treatment available with significant rates of effectiveness, but used only in highly specific cases (LópezMuñoz and Alamo, 2009). Subsequently, it was demonstrated that iproniazid was a monoamine-oxidase (MAO) inhibitor, particularly MAO-A. The role of MAO-A is to convert biogenic (e.g. serotonin and catecholamines) and sympathomimetic (e.g. tyramine and benzylamine) amines into deaminated products (Johnston, 1968). This discovery led to the development of the first class of antidepressants, the MAO inhibitors (MAOIs). Examples of this class include tranylcypromine and phenelzine. Subsequently, the prototype antidepressant molecule, desmethylimipramine, was developed (Ban and Lehmann, 1962). The development of imipramine gave rise to the tricyclic antidepressants (TCAs), a class of drugs whose mechanism of action involves the inhibition of noradrenaline and serotonin reuptake by neurons (Raisman et al., 1979). Later on, the monoamine serotonin was related to the pathophysiology of depression (Lapin and Oxenkrug, 1969). Based on this discovery, the first family of psychoactive drugs with a rational design, the serotonin-specific re-uptake inhibitors (SSRIs) was developed (Altamura et al., 1988). Fluoxetine was thus the first SSRI synthesized, quickly becoming one of the most prescribed antidepressants in the world (Altamura et al., 1988; López-Muñoz and Alamo, 2009). Therefore, thanks to the discovery and subsequent therapeutic use of TCAs and MAOIs, in the 1960s, the monoaminergic theories of depression were developed (López-Muñoz and Alamo, 2009).

Despite the development of different classes of antidepressant drugs, still today delayed onset of action and high rates of drug resistance are the major limitations of antidepressant therapy. These limitations may possibly be related to other mechanisms, than monoamines deficiency, involved in the pathophysiology of depression. Visa-vis, oxidative/nitrosative stress, neuroinflammation, hypothalamicpituitary-adrenal (HPA) axis, neurogenesis/neurotrophins and ion channels have been important approaches for research in this field (Bakunina et al., 2015; Castrén and Rantamäki, 2010; Iijima et al., 2010; Maes, 2011; Moylan et al., 2014). More recently, on the basis of the important evidences about the role of gut microbiota in the regulation of behavior and in the pathophysiology of several mental disorders, among them depression, the gut-brain axis and its regulation has been subject of many studies (Foster and McVey Neufeld, 2013).

Dysbiosis refers to an altered balance of the gut microbiota. Indeed, dysbiosis is characterized by decreases in commensal bacteria, most notably the phyla Bacteroidetes and Firmicutes, including the clinically relevant Faecalibacterium prausnitzii and increases in adherent/ invasive Escherichia coli (Jones et al., 2014). This gut microbiota imbalance is also observed in patients suffering from intestinal and extra-intestinal disorders, i.e. allergy, asthma, metabolic syndrome, cardiovascular disease, and obesity (Carding et al., 2015). Interestingly, both intestinal and extra-intestinal disorders are comorbidities of MDD
(Filipovic and Filipovic, 2014; Mayer et al., 2001).

Based on iproniazid antidepressant effects, it is not surprisingly that, at present, drugs belonging to new classes of antidepressants still have antimicrobial effects. In this regard, the antimicrobial effects of antidepressants range from weak to strong depending on the drug (Munoz-Bellido et al., 2000a). For instance, several new antidepressant drugs such as sertraline, fluoxetine, escitalopram and older drugs such as tranylcypromine and imipramine present antimicrobial effects (Lieb, 2004; Munoz-Bellido et al., 2000a). Conversely, $\beta$-lactams and tetracyclines also have potential antidepressant properties (Mello et al., 2013; Miyaoka et al., 2012). However, some antimicrobials, such as fluoroquinolones, have also been associated with neuropsychiatric adverse events and mood dysregulation, including depression (Ahmed et al., 2011; Grassi et al., 2001), manic (Bhalerao et al., 2006) and anxiety disorders (Kaur et al., 2016; Rollof and Vinge, 1993).

Thus, in the light of: i) the involvement of dysbiosis in depression and its comorbidities, ii) the antimicrobial effect of some antidepressant drugs and iii) the evidences for antidepressant effect of some antimicrobial agents; this review aims to compile the studies regarding the influences of gut microbiota in behavior and depression as well as to give evidences of antimicrobial effect of antidepressant drugs. We aim to further discuss the possible contribution of the antimicrobial effect of antidepressant drugs to its effectiveness/resistance.

\section{Methods}

For this narrative review, articles published in English from November 1984 to February 2016 were searched in relevant web datasets (PubMed, SciELO, LILACS, PsycINFO, and ISI Web of Knowledge). Search terms included combinations of the following: "MDD and gut microbiota"; "MDD and dysbiosis"; "behavior and germfree animals"; "behavior and gut microbiota"; "antimicrobials and antidepressant activity"; "antidepressants and antimicrobial activity". Two authors (AJMCF and DM) performed independent search of the articles. Four authors selected the relevant articles (DM, CNSS, AJMCF and JQ). Observational, experimental studies in humans and animal models and literature reviews were considered in the search. Inclusion criteria were pre-specified as the following: i) behavioral alterations induced by gut microbiota dysbiosis; ii) effects of stress and depression in gut microbiota, iii) original studies (in vitro and in vivo) and review papers presenting the antimicrobial effect of antidepressants and vice versa and iv) originality and the overall methodological quality of the studies. An exclusion criterion was being a conference abstract. The search retrieved 181 articles, 120 of which were selected.

\section{Results}

\subsection{Gut microbiota and depression}

\subsubsection{Gut microbiota composition}

The human gut contains a complex ecosystem, called intestinal microflora, consisting of a wide range of bacteria (Gerritsen et al., 2011). Studies have estimated that the intestinal microflora has at least 1800 bacterial genera and over 40,000 species of these microorganisms, which together possess about 100 times more genes than the human genome (Forsythe et al., 2010). Recently, the structure of the microbial flora has been better elucidated. Despite the presence of many phyla of bacteria in the gut, the most prominent are the Firmicutes and Bacteriodes. These phyla comprise $70-75 \%$ of the gut microbiota with a Firmicutes/Bacteriodetes ratio of 10.9 in adult individuals (Mariat et al., 2009).

The composition of the gut microbiota varies among individuals (Gerritsen et al., 2011; Mariat et al., 2009). Indeed, the gut microbiota is an extremely dynamic entity, influenced by factors such as genetics, age, diet, metabolism, geography and stress (Mariat et al., 2009; 
Yatsunenko et al., 2012). In this regard, it was recently suggested that the gut microbiota could be considered a good representation of the genetic and environmental history of a person also contributing to the individual risks of acquiring diseases and response to therapy (Foster and McVey Neufeld, 2013).

Increasing studies points to the importance of gut microbiota to the function of the central nervous system (CNS) (Heijtz et al., 2011). The gut-brain communication involves multiple pathways, such as the autonomic nervous system, the enteric nervous system, the neuroendocrine system and the immune system. Despite the involvement of the aforementioned pathways in this communication, preclinical studies revealed that microbiota seems to present a central role in this function (Foster and McVey Neufeld, 2013).

\subsubsection{Behavioral alterations induced by the manipulation of gut microbiota}

The evidences of the role of gut microbiota in behavior regulation came from studies with germ-free (GF) animals (Neufeld et al., 2011; Sudo et al., 2004). Importantly, the behavioral alterations of GF animals were observed in several strains of rodents genetically distinct, strengthening the microbiota-behavior relationship (Clarke et al., 2013; Heijtz et al., 2011; Neufeld et al., 2011). Furthermore, GF animals when exposed to antibiotics, probiotics or pathogenic intestinal bacteria presents distinct behavioral alterations, indicating that the behavioral response and brain function of these animals are significantly impacted when the intestinal bacterial status changes (Collins and Bercik, 2009).

Studies have shown that GF animals have decreased anxiety-like behavior in validated tests such as elevated plus maze, light-dark test and open field tests. The overall reconstruction of the gut microbiota of these animals in early stages of life (up to 6 weeks) partially normalized their behavior, while its reconstitution in adult life, maintained the altered behavioral pattern (Neufeld et al., 2011). Deserves mention the fact that some brain alterations presented by GF animals are also observed in depressed patients. As examples of these alterations are reduced levels of the neurotrophin brain-derived neurotrophic factor (BDNF) (Bercik et al., 2011) and changes in the expression of 5hydroxytryptamine (serotonin) receptor 1A (5HT)-1A (Neufeld et al., 2011). Accordingly, increases in BDNF levels, 5-HT1A autoreceptor desensitization and increased 5-HT1A receptor postsynaptic activation are related to the mechanism of action of some antidepressants (Czesak et al., 2012).

An increase in exploratory behavior and hippocampal levels of BDNF was observed in GF BALB/c mice colonized with microbiota from NIH Swiss mice, while the colonization of GF NIH Swiss mice with BALB/c microbiota reduced exploratory behavior (Bercik et al., 2011). In the same study the administration of oral antimicrobials to specific pathogen free (SPF) mice transiently altered the composition of the microbiota and increased exploratory behavior as well as hippocampal expression of BDNF. The changes observed in Bercik et al. (2011) study were independent of inflammatory activity, changes in levels of gastrointestinal neurotransmitters, and vagal or sympathetic integrity.

Taken together, these preclinical studies demonstrate that the intestinal bacterial status in early developmental periods is of great importance to the regulation of behavioral patterns.

\subsubsection{Stress-induced alterations in gut microbiota}

Early life stress is associated with several disorders ranging from depression to irritable bowel syndrome (Carr et al., 2013; Qin et al., 2014). In line with these studies, it was observed that rat pups when submitted to the model of depression by maternal separation combined with lipopolysaccharide (LPS) challenge, presented higher levels of plasma corticosterone, cytokines (e.g. TNF- $\alpha$ and IFN- $\gamma$ ), increased visceral sensitivity and alteration in the $16 \mathrm{~S}$ ribosomal RNA gene profile of the fecal microbiota when compared to the control group
(O’Mahony et al., 2009).

Also, the exposition of GF animals to moderate restraint stress was associated with higher levels of adrenocorticotropic hormone (ACTH) and corticosterone when compared to SPF animals (Sudo et al., 2004). This increase in ACTH and corticosterone release was completely reversed by GF colonization with Bifidobacterium infantis, a specie of bifidobacteria commonly present in the gastrointestinal tract during childhood, while only partially reversed by nonspecific flora colonization (Collins and Bercik, 2009; Desbonnet et al., 2010). Noteworthy, this reversal of stress response was observed only in animals colonized during early stage of postnatal life. On the contrary, colonization of GF animals with enteropathogenic Escherichia coli during early postnatal life exacerbated the HPA axis response to stress. These studies points towards the important role of the gut microbiota in early stages of life to the development of an appropriate stress feedback mechanism during adulthood (Cryan and Dinan, 2012).

Stressful events during adulthood may also change the structure of gut microbiota (Bailey et al., 2011) and stimulate bacterial translocation (Nettelbladt et al., 2003). In this context, mice exposed to chronic restraint stress presented significant reduction of bacteria genus Bacteriodes spp. and increase of genus Clostridium spp. in cecum samples. These animals also presented higher levels of the pleiotropic cytokine interleukin (IL)- 6 and of the chemokine C-C motif chemokine ligand-2 (CCL)-2 (Bailey et al., 2011). Other elegant study showed that adult rats subjected to chronic mild stress (CMS), an acknowledged animal model of depression, presented increased plasma levels of LPS, LPS-binding protein and increased brain levels of the LPS receptor, toll-like receptor 4 (TLR4). Also, CMS increased the levels of interleukin-1 beta (IL-1 $\beta$ ), prostaglandin-endoperoxide synthase 2 (COX2 ), prostaglandin (PG)-E2 and lipid peroxidation while reduced the levels of the anti-inflammatory prostaglandin 15-Deoxy-Delta-12, 14prostaglandin J2 (15D-PGJ2) in brain tissue. Intestinal decontamination, by the use of gram-negative spectrum antibiotics, reduced brain levels of the pro-inflammatory parameters, decreased the systemic levels of corticosterone and LPS as well as increased the levels of the anti-inflammatory prostaglandin 15D-PGJ2 (Gárate et al., 2011).

The suggested mechanisms underlying stress-induced alterations in gut microbiota are related to sympathetic neural activation and cortisol effects in gut permeability and microbiota composition. In this context, several studies suggest that the activation of noradrenergic fibers located close to intestinal lymphoid organs would facilitate the presentation of enteric bacteria to immune cells of the intestinal mucosa (Lyte, 2011). Indeed, injection of adrenaline in this intestinal epithelium has been shown to increase the capture of pathogenic bacteria in the lymphoid follicles. Also, norepinephrine release stimulates the growth of enteropathogenic bacteria, such as some strains of $E$. coli as well as influences bacterial adherence to the intestinal epithelium (Bailey et al., 2011; Chen et al., 2003; Collins et al., 2012). In relation to cortisol, the activation of HPA axis and the resulting increase in this hormone secretion can cause a local (in the gut) and systemically alteration in immune cells (including cytokine secretion). Cortisol can also alter gut permeability (by increasing gut permeability resulting in enhanced circulating levels of immunomodulatory bacterial components such as LPS) and barrier function as well as change gut microbiota composition towards a more endotoxigenic bacterial strains, such as Coprococcus, Pseudobutyrivibrio and Dorea (Bailey et al., 2011; Cryan and Dinan, 2012).

The traffic of information between the gut and brain involves vagal afferent fibers. This was demonstrated by studies showing that the beneficial effects of the ingestion of probiotics are abolished by vagotomy (Bravo et al., 2011; Perez-Burgos et al., 2013). Of note, Bravo and colleagues showed that the probiotic Lactobacillus rhamnosus (JB-1) reduced stress-induced behavioral (anxiety and depression) and corticosterone release, while non stressed animals fed with JB-1 presented region-dependent alterations in GABAAa2 and GABAB1b mRNA in the brain. These neurochemical and behavioral 
alterations were abolished in vagotomized mice (Bravo et al., 2011).

In conclusion, under conditions of stress the activation of HPA axis and sympathetic neural system can disrupt gut permeability and change gut microbiota composition, increasing the circulating levels of immunostimulant bacterial cell wall components such as LPS. These bacterial compounds could promote a local and systemic inflammation response with important consequences to brain biochemistry. Conversely, the gut microbiota and probiotic agents can alter the levels of circulating cytokines, and this can have a marked effect on brain function. Furthermore, vagus nerve is strongly implicated in the traffic of information from gut microbiota to the brain (Cryan and Dinan, 2012; Lyte, 2011).

\subsubsection{Dysbiosis in depression}

As previously mentioned the gut microbiota presents several beneficial functions to the host, such as: i) protection against pathogenic microorganisms, ii) supply of some essential nutrients to the body, iii) contribution to the metabolism of certain drugs and iv) participation in the absorption and storage of fatty acids (Arumugam et al., 2011). Taking into account the protective functions of gut microbiota, the disruption of the symbiotic relationship between the microbiota and the gastrointestinal tract, i.e. dysbiosis, compromises several functions of the host contributing to the weakening of the immune-intestinal epithelial barrier resulting in bacterial translocation. Of note, small intestinal exposure to bacteria is one powerful trigger of zonulin release, a protein related to intestinal permeability (Fasano, 2011). Zonulin signaling causes rearrangements of actin filaments and induces the displacement of proteins from the junctional complex, thereby increasing gut permeability (Tripathi et al., 2009). High levels of zonulin have been observed in autoimmune and inflammatory diseases (Fasano, 2011). Conversely, autoimmune diseases such as irritable bowel syndrome and pseudomembranous colitis present dysfunction of the intestinal epithelial barrier (Al-Asmakh et al.; Daneman and Rescigno, 2009), being also comorbidities of MDD (Mayer et al., 2001).

Regarding mental disorders, dysbiosis is being observed in patients suffering from schizophrenia, anxiety disorders and depression (Dinan et al., 2014; Foster and McVey Neufeld, 2013). Specifically in MDD patients, a recent study with 46 patients with depression, 29 with MDD (active-MDD), 17 in response to antidepressant treatment (respondedMDD) and 30 healthy controls (HCs) revealed increased levels of Bacteroidetes, Proteobacteria, and Actinobacteria, and reduction of Firmicutes in active-MDD and responded-MDD groups compared to the HC group. Also the MDD group had increased levels of Enterobacteriaceae and Alistipes, but reduced levels of Faecalibacterium (Jiang et al., 2015). Deserves mention the fact that Alistipes species are indole-positive microorganisms influencing thus tryptophan availability (Song et al., 2006). Knowing that tryptophan is the precursor of serotonin, increased abundance of Alistipes might therefore disrupt the balance of the intestinal serotonergic system. In this regard, Saulnier et al. (2011) found that higher levels of Alistipes were associated with a greater frequency of abdominal pain in patients with irritable bowel syndrome speculating thus that Alistipes are associated with gut inflammation. Furthermore, Enterobacteriaceae family seems to be better adapted for survival in the inflamed gut than are the anaerobic commensals dominant in healthy individuals (Lupp et al., 2007).

Using a large study group of 112 MDD patients and 28 normal controls Maes et al. (2012) demonstrated increased median values of serum IgM and IgA against LPS of the gut commensals Gram-negative Enterobacteria, Hafnia alvei, Pseudomonas aeruginosa, Morganella morganii, Pseudomonas putida, Citrobacter koseri, and Klebsiella pneumoniae in MDD patients when compared to controls. These findings indicate that translocated gut commensal bacteria activate immune cells eliciting IgA and IgM responses and that this phenomenon may play a role in the pathophysiology of chronic depression by causing progressive amplifications of immune pathways. The authors concluded that bacterial translocation may occur secondary to systemic inflammation in depression intensifying and perpetuating the primary inflammatory response once the commensals are translocated or be a primary trigger factor associated with the onset of depression in some vulnerable individuals (Maes et al., 2012).

In summary, dysbiosis, increased gut permeability and bacterial translocation are observed in MDD triggering local and systemic immune response (Jiang et al., 2015; Maes et al., 2012, 2008). In line with this evidence, clinical studies with MDD patients have found increased bacterial translocation and a secondary immune response as a consequence of this translocation (Maes et al., 2012). Together, the weakening of the intestinal epithelial barrier and bacterial translocation influence the central nervous system maintaining the neuroinflammatory alterations in MDD (Cryan and Dinan, 2012; Walker et al., 2014a).

\section{Antidepressant agents with antimicrobial effect}

As previously mentioned, since its historical origin antidepressant drugs present antimicrobial effects (Chessin et al., 1957; Kristiansen, 1990; Munoz-Bellido et al., 2000b; Lieb, 2004). Currently, the treatment of depression by antidepressants is associated with mechanism unrelated to the antimicrobial effect of these drugs.

In this context, iproniazid shares similar properties with isoniazid. The mechanism of isoniazid bactericidal activity is through formation of isonicotinoyl radicals. These radicals react with the bacterial cofactors NAD and NADPH and produce various compounds capable of inhibiting bacterial cell-wall synthesis (Jena et al., 2014; Lei et al., 2000). Iproniazid is a MAOI. On the basis of its antimicrobial effect, MAOIs can remit infectious diseases such as aphthous ulcers, labialgenital herpes and respiratory infections (Liang et al., 2013). Despite the antimicrobial effects of MAOIs, as far as we know, there are no specific reference in the literature to the antimicrobial mechanism of action of isoniazid-iproniazid derivatives, i.e. isocarboxazid, phenelzine, tranylcypromine and moclobemide, drugs used for the management of treatment-resistant depression (Obregon et al., 2012; Thase, 2012).

Another class of antidepressant drugs, the TCAs, was reported to prevent the growth of intestinal pathogens such as E. coli, Yersinia enterocolitica (Csiszar and Molnar; Molnár, 1988) and Giardia lamblia (Weinbach et al., 1992). Furthermore, TCAs present antiplasmid activity (Molnár, 1988). Bacterial plasmids are extrachromosomal elements that carry genes conferring resistance to one or more antibiotics. The two potential targets for the action of TCAs against plasmids are the replicating plasmid DNA and the DNA gyrase enzyme, both essential for DNA structural conformation. Thus, given that bacterial conjugation is the major source of bacterial genetic advantage, this effect of TCAs opens perspectives for dealing with the major problem of multi resistant strains of bacteria (Csiszar and Molnar; Molnár et al., 1995). Besides this, TCAs presented in vitro activity against Plasmodium falciparum (Bitonti et al., 1988; Salama and Facer, 1990) and Leishmania spp. (Zilberstein and Dwyer, 1984).

The antimicrobial effect of the SSRIs sertraline, fluoxetine and paroxetine is especially against Gram-positive bacteria such as Staphylococcus and Enterococcus (Ayaz et al., 2015; Coban et al., 2009; Munoz-Bellido et al., 2000b). In addition, the SSRIs present good activity against potentially toxigenic Enterobacteria, such as Citrobacter spp, P. aeruginosa, K. pneumoniae and M. morganii, and anaerobic, such as Clostridium perfringens and Clostridium difficile (Kruszewska et al., 2012; Munoz-Bellido et al., 2000b).

The mechanisms underlying SSRIs antimicrobial effects are not fully understood. One proposed mechanism is inhibition of efflux pumps. This effect may explain the synergistic effect of SSRIs in combination with certain antibiotics, as well as its effects against some strains of bacteria resistant to antimicrobial agents (Bohnert et al., 
2011; Gjestad et al., 2015). This synergistic effect is confirmed by decreases in the minimum inhibitory concentrations (MICs) of antibiotics when combined with antidepressants (J. L. Munoz-Bellido et al., 2000b; Muñoz-Bellido et al., 1996). In this regard, synergistic effects were observed by the combination of some antidepressant drugs and antibiotics against resistant microorganisms such as Corynebacterium urealyticum (Kristiansen et al., 2007; Munoz-Bellido et al., 2000b; Muñoz-Bellido et al., 1996).

Table 1

Chemical structure of some antidepressant drugs with their related antimicrobial action. Source of the chemical structures: PubChem.

Chemical structure $\quad$ Antimicrobial Action<smiles>CN[C@H]1CC[C@H](c2ccc(Cl)c(Cl)c2)c2ccccc21</smiles>

S. aureus, Bacillus subtilus, E. coli, Shigella dysenteriae, Salmonella spp., Vibrio cholerae, C. albicans, C. tropicalis, C. parapsilosis, Aspergillus spp., Corynebacterium urealyticum
Munoz-Bellido et al. (1996); Samanta (2015); Lass-Florl (2001)

\section{Sertraline}<smiles>CNCCC(Oc1ccc(C(F)(F)F)cc1)c1ccccc1</smiles>

Fluoxetine<smiles>Fc1ccc([C@H]2CCNC[C@H]2COc2ccc3c(c2)OCO3)cc1</smiles>

\section{Paroxetine}<smiles>CN(C)CCC=C1c2ccccc2CCc2ccccc21</smiles>

\section{Amitriptyline}<smiles>CN(C)CCCC1(c2ccc(F)cc2)OCc2cc(C#N)ccc21</smiles>

Escitalopram
Gram positive bacteria, H. influenzae, M. catarrhales, Campylobacter jejuni, Aspergillus spp. and C. parapsilosis

Gram positive bacteria, $H$. influenzae $M$. catarrhales and Campylobacter jejuni

S. areus, K. pneumoniae, Shigella spp., Bacillus spp., Salmonella spp., E. coli, Vibrio cholerae, Vibrio parahaemolyticus, P. aeruginosa, Lactobacillus sporogenes, Citrobacter spp., Cryptococcus spp.

S. aureus, P. aeruginosa, K. pseumoniae, Proteus mirabilis and Enterobacter cloacae.
Munoz-Bellido et al. (2000a); Lass-Florl (2001)

(Munoz-Bellido et al., 2000a); Lass-Florl (2001)
Mandal et al. (2010); (Muthukumar and Janakiraman, 2014)
Akilandeswari; Ruckmani;
Ranjithmathan, 2013. 
Ketamine also presents antimicrobial activity (Gocmen et al., 2008). This drug is an N-methyl-D-aspartate (NMDA) antagonist with a rapid onset of antidepressant action (Miller et al., 2014). Indeed, in the last decades, several studies have pointed out to the striking antidepressant effects of ketamine, which can emerge into hours and significantly improve the most of depressive symptoms, even in conditions of treatment-resistant depression (Berman et al., 2000; DiazGranados et al., 2010; Ibrahim et al., 2011). Ketamine was effective against some bacterial species, such as Staphylococcus aureus, Staphylococcus epidermidis, Entecoccus faecalis, Streptococcus pyogenes and P. aeruginosa and fungal infections such as Candida albicans (Begec et al., 2013; Kruszewska et al., 2012; Gocmen et al., 2008).

Table 1 and Fig. 1 present the chemical structure, antimicrobial activity against microorganisms and antimicrobial mechanism of action of some antidepressant drugs..

\section{Antimicrobial agents with antidepressant effects}

In recent years antimicrobial compounds were studied for their neuroprotective properties and for their potential as psychotropic medications (Obregon et al., 2012). In this regard drugs like $\beta$-lactam antibiotics, for instance, ceftriaxone, were found to promote the expression of the glutamate transporter GLT1, thus presenting neuroprotective properties in animal models of depression (Mineur et al., 2007). Indeed, glutamatergic transmission has emerged as a potential therapeutic target for the development of antidepressant drugs (Medina et al., 2013; Mineur et al., 2007; Sapolsky, 2000) due to the excessive glutamatergic neurotransmission observed in MDD (For a review please read (Mathews et al., 2012)). The tetracycline, minocycline, has been shown to exhibit immunomodulatory and psychotropic properties possibly unrelated to its antibiotic mechanism of action. Minocycline's psychotropic properties, including the antidepressant activity (Miyaoka et al., 2012) have been attributed, for example, to inhibition of oxidative stress through attenuation of the expression of inducible nitric oxide synthase (iNOS), COX-2, and matrix metalloproteinase (MMP) and regulation in glutamatergic neurotransmission
(Chaves et al., 2009; González et al., 2007; Monte et al., 2013; Réus et al., 2014). Additionally our research group showed that doxycycline, a second-generation tetracycline, also presents antidepressant-like properties against LPS-induced depressive-like behavior in mice (Mello et al., 2013). The antidepressant-like effect of doxycycline was associated to a prevention and reversal of brain oxidative and neuroinflammatory alterations induced by LPS (Mello et al., 2013).

$\mathrm{D}$-cycloserine is a second-line bacteriostatic agent for the treatment of Mycobacterium tuberculosis being also active against susceptible Gram-negative and Gram-positive bacteria including Chlamydia, $S$. aureus, E. coli, Enterococci and Mycobacterium avium complex microorganisms. This drug was evaluated for a variety of uses including the treatment of MDD displaying antidepressant properties at doses considered subtherapeutic for antimicrobial purposes (Crane, 1959). The isoniazid derivatives including isocarboxazid, phenelzine, tranylcypromine and the reversible MAO-A inhibitor, moclobemide, present profound efficacy for treatment-resistant depression. Finally, among the macrolide antibiotics, rapamycin is an agent that inhibits the mammalian target of rapamycin (mTOR). mTOR is a key regulator of cell autophagy by controlling the intracellular levels of aggregated proteins and toxic substrates. The modulation of mTOR seems to be a promising target for neuroprotection and antidepressant therapy (Cleary et al., 2008; Ravikumar et al., 2004; Ravikumar and Rubinsztein, 2004; Tang et al., 2002). In this context, it was demonstrated that enhancement of autophagic process is involved in the mood stabilizing effects of lithium (Sarkar et al., 2005). Furthermore, the subchronic administration of rapamycin $(10 \mathrm{mg} / \mathrm{kg})$ resulted in antidepressant-like effect in rats and mice submitted to forced swim and tail suspension tests (Cleary et al., 2008).

Besides presenting antidepressant mechanisms, as mentioned above in this section, many antibiotics can have unintended and profound effects on the indigenous microbiota. Taking this into account, previous studies observed changes in gut microbiota induced by minocycline and their relation with MDD treatment (Miyaoka et al., 2012).

Overall, the studies regarding alterations in gut microbiota induced

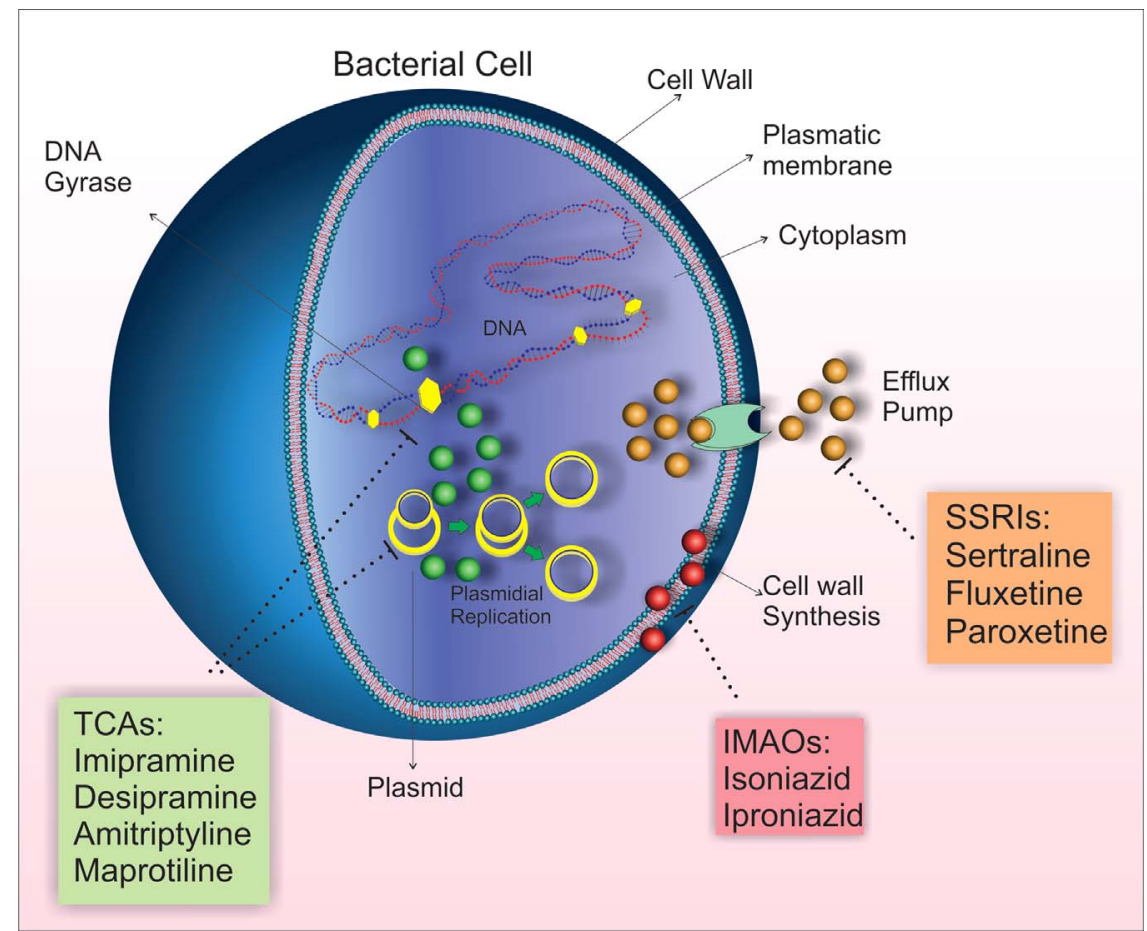

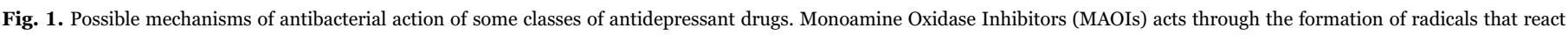

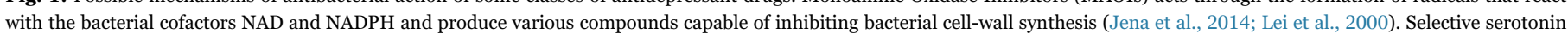
reuptake inhibitors (SSRIs) inhibit efflux pumps (Bohnert et al., 2011; Gjestad et al., 2015). Tricyclic antidepressants (TCAs) present antiplasmid activity (Molnár, 1988). 
by antimicrobial drugs and its relation with the antidepressant effect of these drugs are still incipient. This calls our attention for the need of further studies evaluating the alterations in gut microbiota of MDD patients in clinical protocols designed to study the antidepressant effect of antimicrobials and vice versa.

Fig. 2 presents the chemical structure of some antimicrobial drugs already studied for their antidepressant effects..<smiles>N[C@@H]1CONC1=O</smiles>

Cycloserine

(CRANE, 1959)<smiles>CN(C)c1ccc(O)c2c1C[C@H]1C[C@H]3[C@H](N(C)C)C(O)=C(C(N)=O)C(=O)[C@]3(I)C(O)=C1C2=O</smiles>

Minocycline

(ARAKAWA et al., 2012; MOLINA-HERNÁNDEZ et al., 2008; DEAN et al, 2014; ZHENG; KANEKO; SAWAMOTO, 2015).<smiles>O=C(O)/C=C1/O[C@@H]2CC(=O)N2[C@H]1CO</smiles>

Clavulanic acid

(KOST et al., 2011)<smiles>CO/N=C(/C(=O)N[C@H]1C(=O)N2C(C(=O)O)=C(CSc3nc(=O)c(=O)[nH]n3C)CS[C@H]12)c1csc(N)n1</smiles>

Ceftriaxone

(MINEUR; PICCIOTTO; SANACORA, 2007;

ROTHSTEIN et al., 2005)

\section{Discussion}

As previously mentioned, studies have associated dysbiosis, increased gut permeability and bacterial translocation with the pathophysiology of MDD (Dinan and Cryan, 2013; Jiang et al., 2015; Maes et al., 2012). Conversely, these alterations are also observed in extraintestinal and intestinal comorbidities of MDD, for instance, irritable bowel syndrome (Carding et al., 2015; Fadgyas-Stanculete et al., 2014).<smiles>CN(C)c1ccc2nc3ccc(N(C)C)cc3[o+]c2c1</smiles>

Methylene blue

(EROGLU; CAGLAYAN, 1997)<smiles>C[C@H]1c2cccc(O)c2C(=O)C2=C(O)[C@]3(O)C(=O)C(C(N)=O)C(O)[C@H](N(C)C)[C@]3(C)[C@H](O)[C@@]21C</smiles>

Doxycycline

(MELO et al., 2013)

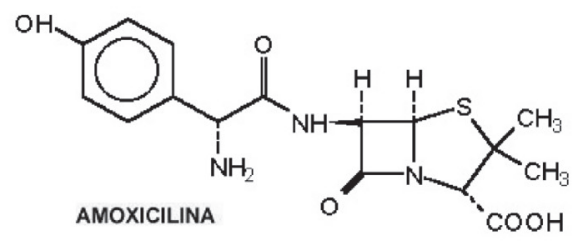

Amoxicillin

(ROTHSTEIN et al., 2005)<smiles>NNC(=O)c1ccncc1</smiles>

Isoniazid

(SALZER; LURIE, 1953; BERMANN, 1955;

OLDHAM, 1955; JOSHI, 1976)

Fig. 2. Chemical structures of antimicrobial drugs and main references related to the antidepressant effect of each drug. 
Intestinal microbial dysbiosis observed in depressed patients is associated with increased levels of gut Bacteroidetes, Enterobacteriaceae, Alistepes and decreased levels of Firmicutes and Faecalibacterium when compared to healthy subjects (Foster and McVey Neufeld, 2013; Maes et al., 2012), triggering local and systemic immune response (Cryan and Dinan, 2012). Intestinal dysbiosis compromises the gutbrain communication as well as triggers increased gut permeability and bacterial translocation. Bacterial translocation in turn leads to increased blood levels of the bacterial endotoxin LPS in MDD patients (Maes et al., 2012). LPS in turn sustains neuroinflammatory alterations induced by depression (Cryan and Dinan, 2012; Walker et al., 2014b).

Based on the alterations in gut microbiota observed in MDD we can suggest that the use of drugs presenting antimicrobial activity (i.e. some antidepressants, as aforementioned or antimicrobials) may present positive or negative effects that needs to be better evaluated in future preclinical and clinical studies. Thus, one possible positive issue related to the use of drugs with antimicrobial effect for the treatment of depression would be the restoration of gut microbiota balance and the reestablishment of homeostatic conditions, leading to an improvement of brain-gut communication. This homeostasis of brain-gut communication may be of relevance to the efficacy of antidepressant drugs. This hypothesis is reinforced by studies showing that sertraline was at least as cost-effective as or more cost-effective for MDD treatment than other antidepressant drugs (Kaplan and Zhang, 2012), being also a strong candidate as the initial choice of antidepressant in people with acute major depression (Cipriani et al., 2010). Deserves mention the fact that sertraline possesses strong intrinsic antibacterial and antifungal activities (Ayaz et al., 2015; Coban et al., 2009). Another point for reflection is that the MAOIs are drugs used for the management of treatment-resistant depression (Thase, 2012) also presenting important antimicrobial effects (Liang et al., 2013). Furthermore, antidepressants are effective for the treatment of irritable bowel syndrome (Clouse, 2003). Of note, patients with irritable bowel syndrome often have pathological gut microbiota (Whitehead et al., 2002).

On the other hand, one negative effect would be the induction of gut microbial alteration or resistance (Hu et al., 2013) due to the chronic use of antidepressants with antimicrobial activity. This is reinforced by the findings of a populational-based study showing that adults with depression and taking specific antidepressants seem to be more likely to develop $C$. difficile infections (Rogers et al., 2013). Noteworthy, $C$. difficile infection is the most commonly diagnosed cause of antibioticassociated diarrhea, and has emerged as a major nosocomial infection, surpassing methicillin-resistant $S$. aureus in some hospitals (Miller et al., 2011). The significantly higher risk of $C$. difficile infection was observed in patients taking both the atypical antidepressants mirtazapine and trazodone together (Rogers et al., 2013).

Therefore, several implications, beneficial or deleterious, not fully understood may result from the chronic use of antidepressant drugs with antimicrobial properties and their effects on gut microbiota. In this context, we hypothesize that these antimicrobial properties of antidepressant drugs could also have some relevance for the development of tardive dysphoria. Tardive dysphoria occurs in treatmentresistant depression. Indeed, patients who develop tardive dysphoria present positive initial response to antidepressant drugs and invariably have received high doses of these agents for prolonged time periods (El-Mallakh et al., 2011). Several mechanisms have been classically implicated in the neurobiology of tardive dysphoria, such as desensitization of neurotransmitter receptors and their transporters (Lira et al., 2003; Meyer et al., 2004). Given the influence of gut microbiota in brain neurochemistry (Bravo et al., 2011; Clarke et al., 2013), we speculate that the chronic use of some antidepressant drugs could lead to adaptive alterations in gut microbiota, such as drug-induced resistance, which could contribute to the development of tardive dysphoria. However, further studies are needed to test this hypothesis.

\section{Conclusion and future directions}

Both antidepressants and antimicrobials present neuroprotective/ antidepressant and antimicrobial effects. One proposition of this review is that the antimicrobial effect of antidepressants could be important for the correction of intestinal dysbiosis observed in MDD patients, restoring then the balance of gut microbiota. Contrary to this idea, the chronic use of drugs presenting antimicrobial effects may be related to the development of adaptive alterations in gut microbiota, which effects could be deleterious. This issue could be of great importance since some patients present treatment-resistant depression, although the association of treatment-resistant depression with gut microbiota has not been studied yet.

Finally, although accumulating evidences support the relevance of the microbiota- gut-brain axis for brain functioning and behavior in health and disease, some caveats need to be considered. First, the relative contributions of several components of microbiota-gut-brain axis, such as immune, neural and endocrine systems, to the development of pathological states, such as depression, need to be clarified. Second, it is fundamental to understand how the several microbial strains differentially affect CNS, for example, how the differences in bacterial cell components, metabolite production and genetic variability could interact with host factors, such as immune system. Third, caution need to be taken when translating animal microbiome studies to humans.

Therefore, future studies elucidating the mechanisms by which microbiota interacts with the gut-brain axis will be crucial to understand its involvement in the pathophysiology of depression and to the development of microbiota-derived therapeutic alternatives. Also, clarifying the real contribution of the antimicrobial effects of antidepressants for MDD treatment as well as determining the long-term consequences of these effects to gut microbiota composition and their implications to clinical outcomes could be a promise and future direction for research.

\section{Authors contributions}

AJMCF, DFL and DM performed the articles search. AJMCF wrote the first draft. DFL and DM wrote the final version of the review. CNS, JQ, HVNJ and TB designed the tables and figure and revised the final version of the manuscript.

\section{References}

Ahmed, A.I.A., van der Heijden, F.M.M.A., van den Berkmortel, H., Kramers, K., 2011. A man who wanted to commit suicide by hanging himself: an adverse effect of ciprofloxacin. Gen. Hosp. Psychiatry. http://dx.doi.org/10.1016/ j.genhosppsych.2010.07.002.

Al-Asmakh M.Anuar F.Zadjali F.Rafter J.Pettersson S.Gut microbial communities modulating brain development and function. Gut Microbes. 3, pp. 366-373. http:// dx.doi.org/10.4161/gmic.21287

Altamura, A.C., Montgomery, S.A., Wernicke, J.F., 1988. The evidence for 20mg a day of fluoxetine as the optimal dose in the treatment of depression. Br. J. Psychiatry, S109-S112.

Arumugam, M., Raes, J., Pelletier, E., Le Paslier, D., Yamada, T., Mende, D.R., Fernandes, G.R., Tap, J., Bruls, T., Batto, J.-M., Bertalan, M., Borruel, N., Casellas, F., Fernandez, L., Gautier, L., Hansen, T., Hattori, M., Hayashi, T., Kleerebezem, M., Kurokawa, K., Leclerc, M., Levenez, F., Manichanh, C., Nielsen, H.B., Nielsen, T., Pons, N., Poulain, J., Qin, J., Sicheritz-Ponten, T., Tims, S., Torrents, D., Ugarte, E., Zoetendal, E.G., Wang, J., Guarner, F., Pedersen, O., de Vos, W.M., Brunak, S., Doré, J., Antolín, M., Artiguenave, F., Blottiere, H.M., Almeida, M., Brechot, C., Cara, C., Chervaux, C., Cultrone, A., Delorme, C., Denariaz, G., Dervyn, R., Foerstner, K.U., Friss, C., van de Guchte, M., Guedon, E., Haimet, F., Huber, W., van Hylckama-Vlieg, J., Jamet, A., Juste, C., Kaci, G., Knol, J., Lakhdari, O., Layec, S., Le Roux, K., Maguin, E., Mérieux, A., Melo Minardi, R., M'rini, C., Muller, J., Oozeer, R., Parkhill, J., Renault, P., Rescigno, M., Sanchez, N., Sunagawa, S., Torrejon, A., Turner, K., Vandemeulebrouck, G., Varela, E., Winogradsky, Y., Zeller, G., Weissenbach, J., Ehrlich, S.D., Bork, P., 2011. Enterotypes of the human gut microbiome. Nature 473, 174-180. http://dx.doi.org/10.1038/nature09944.

Ayaz, M., Subhan, F., Ahmed, J., Khan, A.-U., Ullah, F., Ullah, I., Ali, G., Syed, N.-I.-H., Hussain, S., 2015. Sertraline enhances the activity of antimicrobial agents against pathogens of clinical relevance. J. Biol. Res. (Thessalonikē, Greece) 22, 4. http:// 
dx doi.org/10.1186/s40709-015-0028-1.

Bailey, M.T., Dowd, S.E., Galley, J.D., Hufnagle, A.R., Allen, R.G., Lyte, M., 2011. Exposure to a social stressor alters the structure of the intestinal microbiota: implications for stressor-induced immunomodulation. Brain Behav. Immun. 25 397-407. http://dx.doi.org/10.1016/j.bbi.2010.10.023.

Bakunina, N., Pariante, C.M., Zunszain, P.A., 2015. Immune mechanisms linked to depression via oxidative stress and neuroprogression. Immunology. http:// dx.doi.org/10.1111/imm.12443.

Ban, T.A., Lehmann, H.E., 1962. Clinical trial with desmethylimipramine (G-35020), a new antidepressive compound. Can. Med. Assoc. J. 86, 1030-1031.

Begec, Z., Yucel, A., Yakupogullari, Y., Erdogan, M.A., Duman, Y., Durmus, M., Ersoy, M.O., 2013. The antimicrobial effects of ketamine combined with propofol: an in vitro study. Braz. J. Anesth. 63, 461-465 . http://dx.doi.org/10.1016/ j.bjane.2012.09.004〈doi:〉.

Bercik, P., Denou, E., Collins, J., Jackson, W., Lu, J., Jury, J., Deng, Y., Blennerhassett, P., Macri, J., McCoy, K.D., Verdu, E.F., Collins, S.M., 2011. The intestinal microbiota affect central levels of brain-derived neurotropic factor and behavior in mice. Gastroenterology 141 (599-609), 609-613. http://dx.doi.org/10.1053/ j.gastro.2011.04.052.

Berman, R.M., Cappiello, A., Anand, A., Oren, D.A., Heninger, G.R., Charney, D.S., Krystal, J.H., 2000. Antidepressant effects of ketamine in depressed patients. Biol. Psychiatry 47, 351-354. http://dx.doi.org/10.1016/S0006-3223(99)00230-9.

Bhalerao, S., Talsky, A., Hansen, K., Kingstone, E., Schroeder, B., Karim, Z., Fung, I., 2006. Ciprofloxacin-induced manic episode. Psychosomatics. http://dx.doi.org/ 10.1176/appi.psy.47.6.539.

Bitonti, A.J., Sjoerdsma, A., McCann, P.P., Kyle, D.E., Oduola, A.M., Rossan, R.N. Milhous, W.K., Davidson, D.E., 1988. Reversal of chloroquine resistance in malaria parasite Plasmodium falciparum by desipramine. Science 242, 1301-1303.

Bohnert, J.A., Szymaniak-Vits, M., Schuster, S., Kern, W.V., 2011. Efflux inhibition by selective serotonin reuptake inhibitors in Escherichia coli. J. Antimicrob. Chemother. 66, 2057-2060. http://dx.doi.org/10.1093/jac/dkr258.

Bravo, J.A., Forsythe, P., Chew, M.V., Escaravage, E., Savignac, H.M., Dinan, T.G., Bienenstock, J., Cryan, J.F., 2011. Ingestion of Lactobacillus strain regulates emotional behavior and central GABA receptor expression in a mouse via the vagus nerve. Proc. Natl. Acad. Sci. USA 108, 16050-16055. http://dx.doi.org/10.1073/ pnas.1102999108.

Carding, S., Verbeke, K., Vipond, D.T., Corfe, B.M., Owen, L.J., 2015. Dysbiosis of the gut microbiota in disease. Microb. Ecol. Health Dis. 26, 26191.

Carr, C.P., Martins, C.M.S., Stingel, A.M., Lemgruber, V.B., Juruena, M.F., 2013. The role of early life stress in adult psychiatric disorders: a systematic review according to childhood trauma subtypes. J. Nerv. Ment. Dis. 201, 1007-1020. http://dx.doi.org/ 10.1097/NMD.0000000000000049.

Castrén, E., Rantamäki, T., 2010. The role of BDNF and its receptors in depression and antidepressant drug action: reactivation of developmental plasticity. Dev. Neurobiol. 70, 289-297. http://dx.doi.org/10.1002/dneu.20758.

Chaves, C., Marque, C.R., Trzesniak, C., Machado de Sousa, J.P., Zuardi, A.W., Crippa J.A.S., Dursun, S.M., Hallak, J.E., 2009. Glutamate-N-methyl-D-aspartate receptor modulation and minocycline for the treatment of patients with schizophrenia: an update. Brazilian. J. Med. Biol. Res. 42, 1002-1014. http://dx.doi.org/10.1590/ S0100-879X2009001100002.

Chen, C., Brown, D.R., Xie, Y., Green, B.T., Lyte, M., 2003. Catecholamines modulate Escherichia coli O157: h7 adherence to murine cecal mucosa. Shock 20, 183-188. http://dx.doi.org/10.1097/01.shk.0000073867.66587.e0.

Chessin, M., Kramer, E.R., Scott, C.C., 1957. Modifications of the pharmacology of reserpine and serotonin by iproniazid. J. Pharmacol. Exp. Ther. 119, 453-460.

Cipriani, A., La Ferla, T., Furukawa, T.A., Signoretti, A., Nakagawa, A., Churchill, R, McGuire, H., Barbui, C., 2010. Sertraline versus other antidepressive agents for depression. Cochrane Database Syst. Rev., CD006117. http://dx.doi.org/10.1002/ 14651858.CD006117.pub4.

Clarke, D.M., Currie, K.C., 2009. Depression, anxiety and their relationship with chronic diseases: a review of the epidemiology, risk and treatment evidence. Med. J. Aust. 190, S54-S60.

Clarke, G., Grenham, S., Scully, P., Fitzgerald, P., Moloney, R.D., Shanahan, F., Dinan, T.G., Cryan, J.F., 2013. The microbiome-gut-brain axis during early life regulates the hippocampal serotonergic system in a sex-dependent manner. Mol. Psychiatry 18, 666-673. http://dx.doi.org/10.1038/mp.2012.77.

Cleary, C., Linde, J.A.S., Hiscock, K.M., Hadas, I., Belmaker, R.H., Agam, G., FlaisherGrinberg, S., Einat, H., 2008. Antidepressive-like effects of rapamycin in animal models: implications for mTOR inhibition as a new target for treatment of affective disorders. Brain Res. Bull. 76, 469-473. http://dx.doi.org/10.1016/ j.brainresbull.2008.03.005

Clouse, R.E., 2003. Antidepressants for irritable bowel syndrome. Gut 52, 598-599.

Coban, A.Y., Tanriverdi Cayci, Y., Keles Uludağ, S., Durupinar, B., 2009. Investigation of antibacterial activity of sertralin. Mikrobiyoloji Bül. 43, 651-656.

Collins, S.M., Bercik, P., 2009. The relationship between intestinal microbiota and the central nervous system in normal gastrointestinal function and disease. Gastroenterology 136, 2003-2014. http://dx.doi.org/10.1053/j.gastro.2009.01.075.

Collins, S.M., Surette, M., Bercik, P., 2012. The interplay between the intestinal microbiota and the brain. Nat. Rev. Microbiol. 10, 735-742. http://dx.doi.org/ 10.1038/nrmicro2876.

Crane, G.E., 1959. Cyloserine as an antidepressant agent. Am. J. Psychiatry 115, 1025-1026. http://dx.doi.org/10.1176/ajp.115.11.1025.

Cryan, J.F., Dinan, T.G., 2012. Mind-altering microorganisms: the impact of the gut microbiota on brain and behaviour. Nat. Rev. Neurosci. 13, 701-712. http:// dx.doi.org/10.1038/nrn3346.

Csiszar, K.Molnar, J., Mechanism of action of tricyclic drugs on Escherichia coli and
Yersinia enterocolitica plasmid maintenance and replication. Anticancer Res. 12, pp 2267-72.

Czesak, M., Le François, B., Millar, A.M., Deria, M., Daigle, M., Visvader, J.E., Anisman, H., Albert, P.R., 2012. Increased serotonin-1A (5-HT1A) autoreceptor expression and reduced raphe serotonin levels in deformed epidermal autoregulatory factor-1 (Deaf-1) gene knock-out mice. J. Biol. Chem. 287, 6615-6627. http://dx.doi.org/ 10.1074/jbc.M111.293027.

Daneman, R., Rescigno, M., 2009. The gut immune barrier and the blood-brain barrier: are they so different? Immunity $31,722-735$. http://dx.doi.org/10.1016/ j.immuni.2009.09.012.

Desbonnet, L., Garrett, L., Clarke, G., Kiely, B., Cryan, J.F., Dinan, T.G., 2010. Effects of the probiotic Bifidobacterium infantis in the maternal separation model of depression. Neuroscience 170, 1179-1188. http://dx.doi.org/10.1016/ j.neuroscience.2010.08.005.

DiazGranados, N., Ibrahim, L.A., Brutsche, N.E., Ameli, R., Henter, I.D., Luckenbaugh, D.A., Machado-Vieira, R., Zarate, C.A., 2010. Rapid resolution of suicidal ideation after a single infusion of an N-methyl-D-aspartate antagonist in patients with treatment-resistant major depressive disorder. J. Clin. Psychiatry 71, 1605-1611. http://dx.doi.org/10.4088/JCP.09m05327blu.

Dinan, T.G., Cryan, J.F., 2013. Melancholic microbes: a link between gut microbiota and depression? Neurogastroenterol. Motil. 25, 713-719. http://dx.doi.org/10.1111/ nmo.12198.

Dinan, T.G., Borre, Y.E., Cryan, J.F., 2014. Genomics of schizophrenia: time to consider the gut microbiome? Mol. Psychiatry 19, 1252-1257. http://dx.doi.org/10.1038/ mp.2014.93.

El-Mallakh, R.S., Gao, Y., Jeannie Roberts, R., 2011. Tardive dysphoria: the role of long term antidepressant use in-inducing chronic depression. Med. Hypotheses 76, 769-773. http://dx.doi.org/10.1016/j.mehy.2011.01.020.

Fadgyas-Stanculete, M., Buga, A.-M., Popa-Wagner, A., Dumitrascu, D.L., 2014. The relationship between irritable bowel syndrome and psychiatric disorders: from molecular changes to clinical manifestations. J. Mol. Psychiatry 2, 4. http:// dx.doi.org/10.1186/2049-9256-2-4.

Fasano, A., 2011. Zonulin and its regulation of intestinal barrier function: the biological door to inflammation, autoimmunity, and cancer. Physiol. Rev. 91, 151-175. http:// dx.doi.org/10.1152/physrev.00003.2008.

Ferrari, A.J., Charlson, F.J., Norman, R.E., Patten, S.B., Freedman, G., Murray, C.J.L., Vos, T., Whiteford, H.A., 2013. Burden of depressive disorders by country, sex, age, and year: findings from the global burden of disease study 2010. PLoS Med. 10, e1001547. http://dx.doi.org/10.1371/journal.pmed.1001547.

Filipovic, B.R., Filipovic, B.F., 2014. Psychiatric comorbidity in the treatment of patients with inflammatory bowel disease. World J. Gastroenterol. 20, 3552-3563. http:// dx.doi.org/10.3748/wig.v20.i13.3552.

Forsythe, P., Sudo, N., Dinan, T., Taylor, V.H., Bienenstock, J., 2010. Mood and gut feelings. Brain Behav. Immun. 24, 9-16. http://dx.doi.org/10.1016/ j.bbi.2009.05.058.

Foster, J.A., McVey Neufeld, K.-A., 2013. Gut-brain axis: how the microbiome influences anxiety and depression. Trends Neurosci. 36, 305-312. http://dx.doi.org/10.1016/ j.tins.2013.01.005.

Gárate, I., García-Bueno, B., Madrigal, J.L.M., Bravo, L., Berrocoso, E., Caso, J.R., Micó, J.A., Leza, J.C., 2011. Origin and consequences of brain Toll-like receptor 4 pathway stimulation in an experimental model of depression. J. Neuroinflamm. 8, 151. http://dx.doi.org/10.1186/1742-2094-8-151.

Gerritsen, J., Smidt, H., Rijkers, G.T., de Vos, W.M., 2011. Intestinal microbiota in human health and disease: the impact of probiotics. Genes Nutr. 6, 209-240. http:// dx.doi.org/10.1007/s12263-011-0229-7.

Gjestad, C., Westin, A.A., Skogvoll, E., Spigset, O., 2015. Effect of proton pump inhibitors on the serum concentrations of the selective serotonin reuptake inhibitors citalopram, escitalopram, and sertraline. Ther. Drug Monit. 37, 90-97. http:// dx.doi.org/10.1097/FTD.0000000000000101.

Gocmen, S., Buyukkocak, U., Caglayan, O., 2008. In vitro investigation of the antibacterial effect of ketamine. Ups. J. Med. Sci. 113, 39-46.

González, J.C., Egea, J., Del Carmen Godino, M., Fernandez-Gomez, F.J., Sánchez-Prieto, J., Gandía, L., García, A.G., Jordán, J., Hernández-Guijo, J.M., 2007. Neuroprotectant minocycline depresses glutamatergic neurotransmission and $\mathrm{Ca}(2+)$ signalling in hippocampal neurons. Eur. J. Neurosci. 26, 2481-2495. http:// dx.doi.org/10.1111/j.1460-9568.2007.05873.x.

Grassi, L., Biancosino, B., Pavanati, M., Agostini, M., Manfredini, R., 2001. Depression or hypoactive delirium? A report of ciprofloxacin-induced mental disorder in a patient with chronic obstructive pulmonary disease. Psychother. Psychosom. 70, 58-59, (doi:56226).

Heijtz, R.D., Wang, S., Anuar, F., Qian, Y., Björkholm, B., Samuelsson, A., Hibberd, M.L., Forssberg, H., Pettersson, S., 2011. Normal gut microbiota modulates brain development and behavior. Proc. Natl. Acad. Sci. USA 108, 3047-3052. http:// dx.doi.org/10.1073/pnas.1010529108.

Hu, Y., Yang, X., Qin, J., Lu, N., Cheng, G., Wu, N., Pan, Y., Li, J., Zhu, L., Wang, X., Meng, Z., Zhao, F., Liu, D., Ma, J., Qin, N., Xiang, C., Xiao, Y., Li, L., Yang, H., Wang J., Yang, R., Gao, G.F., Wang, J., Zhu, B., 2013. Metagenome-wide analysis of antibiotic resistance genes in a large cohort of human gut microbiota. Nat. Commun. 4, 2151. http://dx.doi.org/10.1038/ncomms3151.

Ibrahim, L., Diazgranados, N., Luckenbaugh, D.A., Machado-Vieira, R., Baumann, J., Mallinger, A.G., Zarate, C.A., 2011. Rapid decrease in depressive symptoms with an $\mathrm{N}$-methyl-D-aspartate antagonist in ECT-resistant major depression. Prog. Neuropsychopharmacol. Biol. Psychiatry 35, 1155-1159. http://dx.doi.org/ 10.1016/j.pnpbp.2011.03.019.

Iijima, M., Ito, A., Kurosu, S., Chaki, S., 2010. Pharmacological characterization of repeated corticosterone injection-induced depression model in rats. Brain Res 1359, 
75-80. http://dx doi.org/10.1016/j.brainres.2010.08.078.

Jena, L., Waghmare, P., Kashikar, S., Kumar, S., Harinath, B.C., 2014. Computational approach to understanding the mechanism of action of isoniazid, an anti-TB drug. Int. J. Mycobacteriol. 3, 276-282. http://dx.doi.org/10.1016/j.ijmyco.2014.08.003. Jenkins, R., 2002. Addressing suicide as a public-health problem. Lancet (Lond., Engl.) 359, 813-814. http://dx.doi.org/10.1016/S0140-6736(02)07958-8.

Jiang, H., Ling, Z., Zhang, Y., Mao, H., Ma, Z., Yin, Y., Wang, W., Tang, W., Tan, Z., Shi, J., Li, L., Ruan, B., 2015. Altered fecal microbiota composition in patients with major depressive disorder. Brain. Behav. Immun. 48, 186-194. http://dx.doi.org/10.1016/ j.bbi.2015.03.016.

Johnston, J.P., 1968. Some observations upon a new inhibitor of monoamine oxidase in brain tissue. Biochem. Pharmacol. 17, 1285-1297.

Jones, M.L., Ganopolsky, J.G., Martoni, C.J., Labbé, A., Prakash, S., 2014. Emerging science of the human microbiome. Gut Microbes 5, 446-457. http://dx.doi.org/ 10.4161/gmic.29810.

Kaplan, C., Zhang, Y., 2012. Assessing the comparative-effectiveness of antidepressants commonly prescribed for depression in the US Medicare population. J. Ment. Health Policy Econ. 15, 171-178.

Kaur, K., Fayad, R., Saxena, A., Frizzell, N., Chanda, A., Das, S., Chatterjee, S., Hegde, S., Baliga, M.S., Ponemone, V., Rorro, M., Greene, J., Elraheb, Y., Redd, A.J., Bian, J., Restaino, J., Norris, L.B., Qureshi, Z.P., Love, B.L., Brookstaver, B.

Georgantopoulos, P., Sartor, O., Raisch, D.W., Rao, G., Lu, K., Ray, P., Hrusheshky, W., Schulz, R., Ablin, R., Noxon, V., Bennett, C.L., Southern Network on Adverse Reactions (SONAR) project, 2016. Fluoroquinolone-related neuropsychiatric and mitochondrial toxicity: a collaborative investigation by scientists and members of a social network. J. Community Support. Oncol. 14, 54-65. http://dx.doi.org/ $10.12788 /$ jcso.0167.

Kristiansen, J.E., 1990. The antimicrobial activity of psychotherapeutic drugs and stereoisomeric analogues. Dan. Med. Bull. 37, 165-182.

Kristiansen, J.E., Hendricks, O., Delvin, T., Butterworth, T.S., Aagaard, L., Christensen, J.B., Flores, V.C., Keyzer, H., 2007. Reversal of resistance in microorganisms by help of non-antibiotics. J. Antimicrob. Chemother. 59, 1271-1279. http://dx.doi.org/ $10.1093 / \mathrm{jac} / \mathrm{dkm} 071$.

Kruszewska, H., Zareba, T., Tyski, S., 2012. Examination of antimicrobial activity of selected non-antibiotic medicinal preparations. Acta Pol. Pharm. 69, 1368-1371.

Lapin, I.P., Oxenkrug, G.F., 1969. Intensification of the central serotoninergic processes as a possible determinant of the thymoleptic effect. Lancet (Lond., Engl.) 1, 132-136.

Lei, B., Wei, C.J., Tu, S.C., 2000. Action mechanism of antitubercular isoniazid. Activation by Mycobacterium tuberculosis KatG, isolation, and characterization of inha inhibitor. J. Biol. Chem. 275, 2520-2526.

Liang, Y., Quenelle, D., Vogel, J.L., Mascaro, C., Ortega, A., Kristie, T.M., 2013. A novel selective LSD1/KDM1A inhibitor epigenetically blocks herpes simplex virus lytic replication and reactivation from latency. MBio 4, e00558-12. http://dx.doi.org/ 10.1128/mBio.00558-12.

Lieb, J., 2004. The immunostimulating and antimicrobial properties of lithium and antidepressants. J. Infect. 49, 88-93. http://dx.doi.org/10.1016/j.jinf.2004.03.006.

Lira, A., Zhou, M., Castanon, N., Ansorge, M.S., Gordon, J.A., Francis, J.H., Bradley-

Moore, M., Lira, J., Underwood, M.D., Arango, V., Kung, H.F., Hofer, M.A., Hen, R., Gingrich, J.A., 2003. Altered depression-related behaviors and functional changes in the dorsal raphe nucleus of serotonin transporter-deficient mice. Biol. Psychiatry 54, 960-971. http://dx.doi.org/10.1016/S0006-3223(03)00696-6.

López-Muñoz, F., Alamo, C., 2009. Monoaminergic neurotransmission: the history of the discovery of antidepressants from 1950s until today. Curr. Pharm. Des. 15, 1563-1586.

Lupp, C., Robertson, M.L., Wickham, M.E., Sekirov, I., Champion, O.L., Gaynor, E.C., Finlay, B.B., 2007. Host-mediated inflammation disrupts the intestinal microbiota and promotes the overgrowth of Enterobacteriaceae. Cell Host Microbe 2, 119-129. http://dx.doi.org/10.1016/j.chom.2007.06.010.

Lyte, M., 2011. Probiotics function mechanistically as delivery vehicles for neuroactive compounds: microbial endocrinology in the design and use of probiotics. Bioessays 33, 574-581. http://dx.doi.org/10.1002/bies.201100024.

Maes, M., 2011. Depression is an inflammatory disease, but cell-mediated immune activation is the key component of depression. Prog. Neuropsychopharmacol. Biol. Psychiatry 35, 664-675. http://dx.doi.org/10.1016/j.pnpbp.2010.06.014.

Maes, M., Kubera, M., Leunis, J.C., 2008. The gut-brain barrier in major depression: intestinal mucosal dysfunction with an increased translocation of LPS from gram negative enterobacteria (leaky gut) plays a role in the inflammatory pathophysiology of depression. Neuroendocrinol. Lett. 29, 117-124, (doi:NEL290108A12 [pii).

Maes, M., Kubera, M., Leunis, J.-C., Berk, M., 2012. Increased IgA and IgM responses against gut commensals in chronic depression: further evidence for increased bacterial translocation or leaky gut. J. Affect. Disord. 141, 55-62. http://dx.doi.org/ 10.1016/j.jad.2012.02.023.

Mariat, D., Firmesse, O., Levenez, F., Guimarăes, V., Sokol, H., Doré, J., Corthier, G., Furet, J.-P., 2009. The Firmicutes/Bacteroidetes ratio of the human microbiota changes with age. BMC Microbiol. 9, 123. http://dx.doi.org/10.1186/1471-2180-9123.

Mathews, D.C., Henter, I.D., Zarate, C.A., 2012. Targeting the glutamatergic system to treat major depressive disorder: rationale and progress to date. Drugs 72 , 1313-1333. http://dx.doi.org/10.2165/11633130-000000000-00000.

Mayer, E.A., Craske, M., Naliboff, B.D., 2001. Depression, anxiety, and the gastrointestinal system. J. Clin. Psychiatry 62 (Suppl 8), S28-S36, (discussion 37).

Medina, A., Burke, S., Thompson, R.C., Bunney, W., Myers, R.M., Schatzberg, A., Akil, H., Watson, S.J., 2013. Glutamate transporters: a key piece in the glutamate puzzle of major depressive disorder. J. Psychiatr. Res. 47, 1150-1156. http://dx.doi.org/ 10.1016/j.jpsychires.2013.04.007.
Mello, B.S.F., Monte, A.S., McIntyre, R.S., Soczynska, J.K., Custódio, C.S., Cordeiro, R.C. Chaves, J.H., Vasconcelos, S.M.M., Nobre, H.V., Florenço de Sousa, F.C., Hyphantis, T.N., Carvalho, A.F., Macêdo, D.S., 2013. Effects of doxycycline on depressive-like behavior in mice after lipopolysaccharide (LPS) administration. J. Psychiatr. Res. 47, 1521-1529. http://dx.doi.org/10.1016/j.jpsychires.2013.06.008.

Meyer, J.H., Wilson, A.A., Sagrati, S., Hussey, D., Carella, A., Potter, W.Z., Ginovart, N., Spencer, E.P., Cheok, A., Houle, S., 2004. Serotonin transporter occupancy of five selective serotonin reuptake inhibitors at different doses: an [11C]DASB positron emission tomography study. Am. J. Psychiatry 161, 826-835. http://dx.doi.org/ 10.1176/appi.ajp.161.5.826.

Miller, B.A., Chen, L.F., Sexton, D.J., Anderson, D.J., 2011. Comparison of the burdens of hospital-onset, healthcare facility-associated Clostridium difficile Infection and of healthcare-associated infection due to methicillin-resistant Staphylococcus aureus in community hospitals. Infect. Control Hosp. Epidemiol. 32, 387-390. http:// dx.doi.org/10.1086/659156.

Miller, O.H., Yang, L., Wang, C.-C., Hargroder, E.A., Zhang, Y., Delpire, E., Hall, B.J., 2014. GluN2B-containing NMDA receptors regulate depression-like behavior and are critical for the rapid antidepressant actions of ketamine. Elife 3, e03581. http:// dx.doi.org/10.7554/eLife.03581.

Mineur, Y.S., Picciotto, M.R., Sanacora, G., 2007. Antidepressant-like effects of ceftriaxone in male C57BL/6J mice. Biol. Psychiatry 61, 250-252. http://dx.doi.org/ 10.1016/j.biopsych.2006.04.037.

Miyaoka, T., Wake, R., Furuya, M., Liaury, K., Ieda, M., Kawakami, K., Tsuchie, K., Taki, M., Ishihara, K., Araki, T., Horiguchi, J., 2012. Minocycline as adjunctive therapy for patients with unipolar psychotic depression: an open-label study. Prog. Neuropsychopharmacol. Biol. Psychiatry 37, 222-226. http://dx.doi.org/10.1016/ j.pnpbp.2012.02.002.

Molnár, J., 1988. Antiplasmid activity of tricyclic compounds. Methods Find. Exp. Clin. Pharmacol. 10, 467-474.

Molnár, J., Bathó, N., Csík, V., Chevalier, J., Cremieux, A., 1995. Interaction between tricyclic psychopharmacons and some antibiotics. Acta Microbiol. Immunol. Hung. 42, 277-285.

Monte, A.S., de Souza, G.C., McIntyre, R.S., Soczynska, J.K., dos Santos, J.V., Cordeiro, R.C., Ribeiro, B.M.M., de Lucena, D.F., Vasconcelos, S.M.M., de Sousa, F.C.F., Carvalho, A.F., Macêdo, D.S., 2013. Prevention and reversal of ketamine-induced schizophrenia related behavior by minocycline in mice: possible involvement of antioxidant and nitrergic pathways. J. Psychopharmacol. 27, 1032-1043. http:// dx.doi.org/10.1177/0269881113503506.

Moylan, S., Berk, M., Dean, O.M., Samuni, Y., Williams, L.J., O’Neil, A., Hayley, A.C Pasco, J.A., Anderson, G., Jacka, F.N., Maes, M., 2014. Oxidative \& nitrosative stress in depression: why so much stress? Neurosci. Biobehav. Rev. 45, 46-62. http://dx.doi.org/10.1016/j.neubiorev.2014.05.007.

Munoz-Bellido, J., Munoz-Criado, S., Garcìa-Rodrìguez, J., 2000a. Antimicrobial activity of psychotropic drugs. Int. J. Antimicrob. Agents 14, 177-180. http://dx.doi.org/ 10.1016/S0924-8579(99)00154-5.

Munoz-Bellido, J.L., Munoz-Criado, S., Garcìa-Rodrìguez, J.A., 2000b. Antimicrobial activity of psychotropic drugs: selective serotonin reuptake inhibitors. Int. J. Antimicrob. Agents 14, 177-180.

Muñoz-Bellido, J.L., Muñoz-Criado, S., García-Rodríguez, J.A., 1996. In-vitro activity of psychiatric drugs against Corynebacterium urealyticum (Corynebacterium group D2). J. Antimicrob. Chemother. 37, 1005-1009.

Nemeroff, C.B., 2007. The burden of severe depression: a review of diagnostic challenges and treatment alternatives. J. Psychiatr. Res. 41, 189-206. http://dx.doi.org/ 10.1016/j.jpsychires.2006.05.008.

Nettelbladt, C.-G., Katouli, M., Bark, T., Svenberg, T., Möllby, R., Ljungqvist, O., 2003. Orally inoculated Escherichia coli strains colonize the gut and increase bacterial translocation after stress in rats. Shock 20, 251-256. http://dx.doi.org/10.1097/ 01.shk.0000068324.41183.c2

Neufeld, K.M., Kang, N., Bienenstock, J., Foster, J.A., 2011. Reduced anxiety-like behavior and central neurochemical change in germ-free mice. Neurogastroenterol. Motil. 23, 255-264. http://dx.doi.org/10.1111/j.1365-2982.2010.01620.x.

O’Mahony, S.M., Marchesi, J.R., Scully, P., Codling, C., Ceolho, A.-M., Quigley, E.M.M., Cryan, J.F., Dinan, T.G., 2009. Early life stress alters behavior, immunity, and microbiota in rats: implications for irritable bowel syndrome and psychiatric illnesses. Biol. Psychiatry 65, 263-267. http://dx.doi.org/10.1016/ j.biopsych.2008.06.026.

Obregon, D., Parker-Athill, E.C., Tan, J., Murphy, T., 2012. Psychotropic effects of antimicrobials and immune modulation by psychotropics: implications for neuroimmune disorders. Neuropsychiatry (Lond.) 2, 331-343. http://dx.doi.org/ $10.2217 /$ npy. 12.41.

Perez-Burgos, A., Wang, B., Mao, Y.-K., Mistry, B., McVey Neufeld, K.-A., Bienenstock, J., Kunze, W., 2013. Psychoactive bacteria Lactobacillus rhamnosus (JB-1) elicits rapid frequency facilitation in vagal afferents. Am. J. Physiol. Gastrointest. Liver Physiol. 304, G211-G220. http://dx.doi.org/10.1152/ajpgi.00128.2012.

Qin, H.-Y., Cheng, C.-W., Tang, X.-D., Bian, Z.-X., 2014. Impact of psychological stress on irritable bowel syndrome. World J. Gastroenterol. 20, 14126-14131. http:// dx.doi.org/10.3748/wjg.v20.i39.14126.

Raisman, R., Briley, M., Langer, S.Z., 1979. Specific tricyclic antidepressant binding sites in rat brain. Nature 281, 148-150. http://dx.doi.org/10.1038/281148a0.

Ravikumar, B., Rubinsztein, D.C., 2004. Can autophagy protect against neurodegeneration caused by aggregate-prone proteins? Neuroreport 15 $2443-2445$

Ravikumar, B., Vacher, C., Berger, Z., Davies, J.E., Luo, S., Oroz, L.G., Scaravilli, F., Easton, D.F., Duden, R., O'Kane, C.J., Rubinsztein, D.C., 2004. Inhibition of mTOR induces autophagy and reduces toxicity of polyglutamine expansions in fly and mouse models of Huntington disease. Nat. Genet. 36, 585-595. http://dx.doi.org/ 
$10.1038 / \mathrm{ng} 1362$.

Réus, G.Z., Abelaira, H.M., Maciel, A.L., Dos Santos, M.A.B., Carlessi, A.S., Steckert, A.V., Ferreira, G.K., De Prá, S.D., Streck, E.L., Macêdo, D.S., Quevedo, J., 2014. Minocycline protects against oxidative damage and alters energy metabolism parameters in the brain of rats subjected to chronic mild stress. Metab. Brain Dis. 30, 545-553. http://dx.doi.org/10.1007/s11011-014-9602-8.

Rogers, M.A.M., Greene, M.T., Young, V.B., Saint, S., Langa, K.M., Kao, J.Y., Aronoff, D.M., 2013. Depression, antidepressant medications, and risk of Clostridium difficile infection. BMC Med. 11, 121. http://dx.doi.org/10.1186/1741-7015-11-121.

Rollof, J., Vinge, E., 1993. Neurologic adverse effects during concomitant treatment with ciprofloxacin, NSAIDS, and chloroquine: possible drug interaction. Ann. Pharmacother. 27, 1058-1059.

Salama, A., Facer, C.A., 1990. Desipramine reversal of chloroquine resistance in wild isolates of Plasmodium falciparum. Lancet (Lond., Engl.) 335, 164-165.

Sapolsky, R.M., 2000. The possibility of neurotoxicity in the hippocampus in major depression: a primer on neuron death. Biol. Psychiatry 48, 755-765.

Sarkar, S., Floto, R.A., Berger, Z., Imarisio, S., Cordenier, A., Pasco, M., Cook, L.J., Rubinsztein, D.C., 2005. Lithium induces autophagy by inhibiting inositol monophosphatase. J. Cell Biol. 170, 1101-1111. http://dx.doi.org/10.1083/ jcb. 200504035 .

Saulnier, D.M., Riehle, K., Mistretta, T.-A., Diaz, M.-A., Mandal, D., Raza, S., Weidler, E.M., Qin, X., Coarfa, C., Milosavljevic, A., Petrosino, J.F., Highlander, S., Gibbs, R., Lynch, S.V., Shulman, R.J., Versalovic, J., 2011. Gastrointestinal microbiome signatures of pediatric patients with irritable bowel syndrome. Gastroenterology 141, 1782-1791. http://dx.doi.org/10.1053/j.gastro.2011.06.072.

Song, Y., Könönen, E., Rautio, M., Liu, C., Bryk, A., Eerola, E., Finegold, S.M., 2006. Alistipes onderdonkii sp. nov. and Alistipes shahii sp. nov., of human origin. Int. J. Syst. Evol. Microbiol. 56, 1985-1990. http://dx.doi.org/10.1099/ijs.0.64318-0.

Sudo, N., Chida, Y., Aiba, Y., Sonoda, J., Oyama, N., Yu, X.-N., Kubo, C., Koga, Y., 2004. Postnatal microbial colonization programs the hypothalamic-pituitary-adrenal system for stress response in mice. J. Physiol. 558, 263-275. http://dx.doi.org/ 10.1113/jphysiol.2004.063388.

Tang, S.J., Reis, G., Kang, H., Gingras, A.-C., Sonenberg, N., Schuman, E.M., 2002. A rapamycin-sensitive signaling pathway contributes to long-term synaptic plasticity in the hippocampus. Proc. Natl. Acad. Sci. USA 99, 467-472. http://dx.doi.org/ 10.1073/pnas.012605299.

Thase, M.E., 2012. MAOIs and depression treatment guidelines. J. Clin. Psychiatry 73, e24. http://dx.doi.org/10.4088/JCP.11096tx4c.

Tripathi, A., Lammers, K.M., Goldblum, S., Shea-Donohue, T., Netzel-Arnett, S., Buzza, M.S., Antalis, T.M., Vogel, S.N., Zhao, A., Yang, S., Arrietta, M.-C., Meddings, J.B., Fasano, A., 2009. Identification of human zonulin, a physiological modulator of tight junctions, as prehaptoglobin-2. Proc. Natl. Acad. Sci. USA 106, 16799-16804. http://dx.doi.org/10.1073/pnas.0906773106.

Vos, T., Flaxman, A.D., Naghavi, M., Lozano, R., Michaud, C., Ezzati, M., Shibuya, K., Salomon, J.A., Abdalla, S., Aboyans, V., Abraham, J., Ackerman, I., Aggarwal, R., Ahn, S.Y., Ali, M.K., Alvarado, M., Anderson, H.R., Anderson, L.M., Andrews, K.G., Atkinson, C., Baddour, L.M., Bahalim, A.N., Barker-Collo, S., Barrero, L.H., Bartels, D.H., Basáñez, M.-G., Baxter, A., Bell, M.L., Benjamin, E.J., Bennett, D., Bernabé, E., Bhalla, K., Bhandari, B., Bikbov, B., Bin Abdulhak, A., Birbeck, G., Black, J.A., Blencowe, H., Blore, J.D., Blyth, F., Bolliger, I., Bonaventure, A., Boufous, S., Bourne, R., Boussinesq, M., Braithwaite, T., Brayne, C., Bridgett, L., Brooker, S., Brooks, P., Brugha, T.S., Bryan-Hancock, C., Bucello, C., Buchbinder, R., Buckle, G., Budke, C.M., Burch, M., Burney, P., Burstein, R., Calabria, B., Campbell, B., Canter, C.E., Carabin, H., Carapetis, J., Carmona, L., Cella, C., Charlson, F., Chen, H., Cheng, A.T.A., Chou, D., Chugh, S.S., Coffeng, L.E., Colan, S.D., Colquhoun, S., Colson, K.E., Condon, J., Connor, M.D., Cooper, L.T., Corriere, M., Cortinovis, M., de Vaccaro, K.C., Couser, W., Cowie, B.C., Criqui, M.H., Cross, M., Dabhadkar, K.C., Dahiya, M., Dahodwala, N., Damsere-Derry, J., Danaei, G., Davis, A., De Leo, D., Degenhardt, L., Dellavalle, R., Delossantos, A., Denenberg, J., Derrett, S., Des Jarlais, D.C., Dharmaratne, S.D., Dherani, M., Diaz-Torne, C., Dolk, H., Dorsey, E.R., Driscoll, T., Duber, H., Ebel, B., Edmond, K., Elbaz, A., Ali, S.E., Erskine, H., Erwin, P.J.,
Espindola, P., Ewoigbokhan, S.E., Farzadfar, F., Feigin, V., Felson, D.T., Ferrari, A., Ferri, C.P., Fèvre, E.M., Finucane, M.M., Flaxman, S., Flood, L., Foreman, K., Forouzanfar, M.H., Fowkes, F.G.R., Franklin, R., Fransen, M., Freeman, M.K., Gabbe, B.J., Gabriel, S.E., Gakidou, E., Ganatra, H.A., Garcia, B., Gaspari, F., Gillum, R.F., Gmel, G., Gosselin, R., Grainger, R., Groeger, J., Guillemin, F., Gunnell, D., Gupta, R., Haagsma, J., Hagan, H., Halasa, Y.A., Hall, W., Haring, D., Haro, J.M., Harrison, J.E., Havmoeller, R., Hay, R.J., Higashi, H., Hill, C., Hoen, B., Hoffman, H., Hotez, P.J., Hoy, D., Huang, J.J., Ibeanusi, S.E., Jacobsen, K.H., James, S.L., Jarvis, D., Jasrasaria, R., Jayaraman, S., Johns, N., Jonas, J.B., Karthikeyan, G., Kassebaum, N., Kawakami, N., Keren, A., Khoo, J.-P., King, C.H., Knowlton, L.M., Kobusingye, O., Koranteng, A., Krishnamurthi, R., Lalloo, R., Laslett, L.L., Lathlean, T., Leasher, J.L., Lee, Y.Y., Leigh, J., Lim, S.S., Limb, E., Lin, J.K., Lipnick, M., Lipshultz, S.E., Liu, W., Loane, M., Ohno, S.L., Lyons, R., Ma, J., Mabweijano, J., MacIntyre, M.F., Malekzadeh, R., Mallinger, L., Manivannan, S., Marcenes, W., March, L., Margolis, D.J., Marks, G.B., Marks, R., Matsumori, A., Matzopoulos, R., Mayosi, B.M., McAnulty, J.H., McDermott, M.M., McGill, N., McGrath, J., MedinaMora, M.E., Meltzer, M., Mensah, G.A., Merriman, T.R., Meyer, A.-C., Miglioli, V., Miller, M., Miller, T.R., Mitchell, P.B., Mocumbi, A.O., Moffitt, T.E., Mokdad, A.A., Monasta, L., Montico, M., Moradi-Lakeh, M., Moran, A., Morawska, L., Mori, R., Murdoch, M.E., Mwaniki, M.K., Naidoo, K., Nair, M.N., Naldi, L., Narayan, K.M.V., Nelson, P.K., Nelson, R.G., Nevitt, M.C., Newton, C.R., Nolte, S., Norman, P., Norman, R., O’Donnell, M., O’Hanlon, S., Olives, C., Omer, S.B., Ortblad, K., Osborne, R., Ozgediz, D., Page, A., Pahari, B., Pandian, J.D., Rivero, A.P., Patten, S.B., Pearce, N., Padilla, R.P., Perez-Ruiz, F., Perico, N., Pesudovs, K., Phillips, D., Phillips, M.R., Pierce, K., Pion, S., Polanczyk, G.V., Polinder, S., Pope, C.A., Popova, S., Porrini, E., Pourmalek, F., Prince, M., Pullan, R.L., Ramaiah, K.D., Ranganathan, D., Razavi, H., Regan, M., Rehm, J.T., Rein, D.B., Remuzzi, G., Richardson, K., Rivara, F.P., Roberts, T., Robinson, C., De Leòn, F.R., Ronfani, L., Room, R., Rosenfeld, L.C., Rushton, L., Sacco, R.L., Saha, S., Sampson, U., Sanchez-Riera, L., Sanman, E., Schwebel, D.C., Scott, J.G., Segui-Gomez, M., Shahraz, S., Shepard, D.S., Shin, H., Shivakoti, R., Singh, D., Singh, G.M., Singh, J.A., Singleton, J., Sleet, D.A., Sliwa, K., Smith, E., Smith, J.L., Stapelberg, N.J.C., Steer, A., Steiner, T., Stolk, W.A., Stovner, L.J., Sudfeld, C., Syed, S., Tamburlini, G., Tavakkoli, M., Taylor, H.R., Taylor, J.A., Taylor, W.J., Thomas, B., Thomson, W.M., Thurston, G.D., Tleyjeh, I.M., Tonelli, M., Towbin, J.A., Truelsen, T., Tsilimbaris, M.K., Ubeda, C., Undurraga, E.A., van der Werf, M.J., van Os, J., Vavilala, M.S.,

Venketasubramanian, N., Wang, M., Wang, W., Watt, K., Weatherall, D.J., Weinstock, M.A., Weintraub, R., Weisskopf, M.G., Weissman, M.M., White, R.A., Whiteford, H., Wiersma, S.T., Wilkinson, J.D., Williams, H.C., Williams, S.R.M., Witt, E., Wolfe, F., Woolf, A.D., Wulf, S., Yeh, P.-H., Zaidi, A.K.M., Zheng, Z.-J., Zonies, D., Lopez, A.D., Murray, C.J.L., AlMazroa, M.A., Memish, Z.A., 2012. Years lived with disability (YLDs) for 1160 sequelae of 289 diseases and injuries 19902010: a systematic analysis for the Global Burden of Disease Study 2010. Lancet 380, 2163-2196. http://dx.doi.org/10.1016/S0140-6736(12)61729-2.

Walker, A.J., Kim, Y., Price, J.B., Kale, R.P., McGillivray, J.A., Berk, M., Tye, S.J., 2014a. Stress, inflammation, and cellular vulnerability during early stages of affective disorders: biomarker strategies and opportunities for prevention and intervention. Front. Psychiatry 5, 34. http://dx.doi.org/10.3389/fpsyt.2014.00034.

Walker, A.K., Kavelaars, A., Heijnen, C.J., Dantzer, R., 2014b. Neuroinflammation and comorbidity of pain and depression. Pharmacol. Rev. 66, 80-101. http://dx.doi.org/ 10.1124/pr.113.008144.

Weinbach, E.C., Levenbook, L., Alling, D.W., 1992. Binding of tricyclic antidepressant drugs to trophozoites of Giardia lamblia. Comp. Biochem. Physiol. C 102, 391-396.

Yatsunenko, T., Rey, F.E., Manary, M.J., Trehan, I., Dominguez-Bello, M.G., Contreras, M., Magris, M., Hidalgo, G., Baldassano, R.N., Anokhin, A.P., Heath, A.C., Warner, B., Reeder, J., Kuczynski, J., Caporaso, J.G., Lozupone, C.A., Lauber, C., Clemente, J.C., Knights, D., Knight, R., Gordon, J.I., 2012. Human gut microbiome viewed across age and geography. Nature 486, 222-227. http://dx.doi.org/10.1038/ nature11053.

Zilberstein, D., Dwyer, D.M., 1984. Antidepressants cause lethal disruption of membrane function in the human protozoan parasite Leishmania. Science 226, 977-979. 